\title{
Faulty Breast Feeding Practice : A Risk Factor in Malnourished Children
}

\author{
Sukhendu Shekhar Sen ${ }^{*}$ \\ Jhulan Das Sharma ${ }^{2}$ \\ Dhananjoy Das $^{3}$ \\ Shahed Iqbal ${ }^{3}$ \\ Md Badruddoza ${ }^{3}$
}

Department of Paediatrics

Chittagong Medical College, Chittagong, Bangladesh.

${ }^{2}$ Department of Paediatrics

Southern Medical College, Chittagong, Bangladesh.

${ }^{3}$ Department of Paediatrics

Chattagram Maa Shishu-O- General Hospital

Chittagong, Bangladesh.
*Correspondence to:

Dr. Sukhendu Shekhar Sen

Assistant Professor

Department of Paediatrics

Chittagong Medical College, Chittagong, Bangladesh Mobile : +8801713207027

E-mail: sukhendusen@gmail.com

www.banglajol.info/index.php/CMOSHMCJ

\begin{abstract}
Background: The predominant form of malnutrition is commonly called proteincalorie malnutrition. Protein Energy Malnutrition (PEM) is still a major health problem in children of developing countries including Bangladesh. The causes of malnutrition are multifactorial including nutritional factors, socioeconomic factors, health status of the mothers and repeated infections in children. Objective: To explore the information regarding the breast feeding practices of children suffering from Protein-Energy Malnutrition. Methods: This case control study was conducted in Chittagong Medical College Hospital from November 2006 to April 2007. A total of 65 controls and 65 cases were selected consecutively for the purpose of the study. Their mothers were interviewed with help of structured questionnaire containing all the variables of interest to attain the study objectives. The test statistics used to analyze the data were descriptive statistics and Chi-square $\left(\chi^{2}\right)$ or Fisher's Exact Probability Test. Results: A significantly higher frequency of cases (67.7\%) were given pre-lacteal feed, predominantly honey and sugar-water compared to control group $(41.5 \%)(p=0.008)$. Nearly $100 \%$ of controls were given colostrums compared to $75 \%$ of the cases. About one-third (31.3\%) of the cases was exclusively breast-fed in comparison to $58.5 \%$ of the control group $(\mathrm{p}=0.003)$. Over onequarter $(27.7 \%)$ of the control were breast-fed upto 6 months of age, as opposed to only $1.5 \%$ cases $(p<0.001)$. Duration of predominant breast feeding for more than 6 months of age was also significantly higher in control group than that in case group $(p=0.001)$. Breast milk substitutes demonstrate their significant presence in cases $(38.5 \%)$ than that in controls $(9 \%)(p=0.003)$. Conclusion: The study showed that rejection of colostrums, practice of prelacteal feeding, delayed initiation of breast feeding, early cessation of exclusive breast feeding and use of formula milk all were significantly higher in the malnourished group of children than those in their normal counterpart.
\end{abstract}

Key words: Protein energy malnutrition; Breastfeeding; Risk factors.

\section{INTRODUCTION}

The term "Protein Energy Malnutrition" (PEM) is used to cover a spectrum of clinical pictures, ranging from frank kwashiorkor to severe marasmus. The description of kwashiorkor given by Williams in her first published article (1933) is as vivid and accurate today as it was more than 50 years ago, although she did not introduce the name kwashiorkor until her second paper in 1935. The earliest account of the syndrome was published by Hinazosa in Mexico in $1865^{1}$.

The predominant form of malnutrition is commonly called Protein-Calorie Malnutrition (PEM) the most serious and widespread nutritional disorder known to medical and nutritional science. To a varying extent, but common to all these forms of protein-calorie malnutrition, are retarded growth and disorder tissue repair (Protein deficiency), and energy storage (Calorie deficiency). Marasmus is total inanition in the child with severe and continued restriction of both calories and protein as well as of all other nutrients. In kwashiorkor dietary protein is of poor quality and restricted in amount; calories are often restricted but may even be in excess of requirements ${ }^{2}$. 


\section{Magnitude of the problem:}

Malnutrition remains one of the most common causes of morbidity and mortality among children throughout the world ${ }^{3}$. Some $49 \%$ of the 10 million deaths among the under-five children each year in the developing world are associated with malnutrition. Those who survive are at risk of disability, stunned mental and physical growth and as a result retarded national socio-economic development ${ }^{4}$. It is estimated that, $26.7 \%$ of the under-five children in the developing countries are affected by protein energy malnutrition and more than twothirds $(70 \%)$ of those children live in Asia (of which $61 \%$ are in south central Asia) $)^{5}$. Malnutrition is a major public health problem in Bangladesh. The Child Nutrition Survey of Bangladesh 2000 showed that about $2.4 \%$ of children were severely malnourished while about $34.7 \%$ were moderately malnourished ${ }^{6}$.

\section{Multifactorial cause of malnutrition:}

Whatever the form of presentation of malnutrition (marasmus or kwashiorkor), the root problem is not necessarily a shortage of food. The causes of malnutrition are multifactorial, including nutritional factors, socioeconomic factors, health status of the mothers and repeated infections in children ${ }^{7}$.

Infection and malnutrition creates a vicious cycle. Diarrhoea, measles, whooping cough, tuberculosis and infestation with helminthes compromise the nutrition of the child. Poor immunization status resulting in the persistence of the vicious cycle of infection and malnutrition ${ }^{1}$.

\section{Faulty feeding practice and malnutrition:}

Faulty Breast feeding practice, including rejection of colostrums is among the most important causes of malnutrition.

Good feeding practice is crucial for under 2 child survival. Exclusive breast feeding is most desirable for 0-6 months age group children. Weaning should be started at 6 months of age. During 6-23 months age breastfeeding and supplementary food (Khichuri, egg, fruit, juices, vegetables, mashed meat, fish successively) are normal feeding. Proper preparation is also important here ${ }^{8}$.

Current breast feeding recommendations ${ }^{9}$

1. Babies should be exclusively breast feed for atleast 6 months.

2. Babies should receive no infant formula or animal milk or drinks or foods other than breast milk until 6 months.

3. No limit should be placed on the number or length of breast feeds.

4. Give the baby no bottles, artificial feeds or pacifiers / dummies.

5. Babies should continue breastfeeding for up to $2 \mathrm{yrs}$ with increasing amounts of complementary foods and cup feed liquids.

\section{OBJECTIVES}

General: To explore the information regarding the breast feeding practices of children suffering from Protein-Energy Malnutrition.

Specific: To identify the faulty breast feeding practices in malnourished children in a hospital set up.

\section{MATERIALS \& METHOD}

A case control design was adopted to conduct the study.

Place and duration of study:

The study was conducted in the "Nutrition Block" of Department of Paediatrics, Chittagong Medical College Hospital during the period from November 2006 to April 2007.

Study population:

Study population was divided into cases and controls.

Case: Moderate to severely wasted children with or without bipedal nutritional oedema and age ranging from $6-59$ months admitted in the "Nutrition Block" of Department of Paediatrics, Chittagong Medical College Hospital were selected as case. Oedema due to renal or liver cause were excluded from the study.

Control: Children of same age range as cases with mild or no wasting without bipedal nutritional oedema admitted in the same hospital for diseases other than malnutrition or attended at OPD or EPI centre were taken as controls.

Sample size: The sample size was determined using the following formula.

$\mathrm{n}=\left(\mathrm{Z}^{2} \times \mathrm{p} \times \mathrm{q}\right) / \mathrm{d}^{2}$, where $\mathrm{Z}=$ Standard normal deviate $=1.96$

$p=$ Prevalence of the disease or event of interest $=0.15$

(as the prevalence of moderate and severe wasting in under five children is $15 \%)$

$\mathrm{q}=(1-\mathrm{p})=0.85$ and

$\mathrm{d}=$ Desired accuracy $=0.05$

Putting the values in the equation we got the required sample size,

$\mathrm{n}=1.96^{2} \times 0.15 \times(1-0.15) /(0.05)^{2}=.196$.

Due to limitation of time, purposive and convenient sampling was done. A total of 65 controls and 65 cases were selected consecutively for the purpose of the study. From the statistical point of view it is significant.

\section{Variables studied:}

The following variables were studied to address the study objectives:

1. Socio-demographic characteristics:

- Age of child.

- Sex of child.

2. Feeding history:

- Prelacteal meal

- Ever breast milk given

- Initiation of breast feeding

- Colostrums intake

- Exclusive breast feeding

- Duration of exclusive breast feeding

- Predominant breast feeding

- Duration of predominant breast feeding

- Breast milk substitution within 6 months of age 
Classification of malnutrition:

- WHO classification

Data collection:

Taking written consent from the parents/attendants of each of the subjects included in the study, data were collected using a structured questionnaire (research instrument) containing all the variables of interest.

\section{Data processing:}

Collected data were checked and edited first. They were then processed with the help of software Statistical Package for Social Sciences (SPSS) version 11.5 and analysed.

Statistical analysis:

Statistical analyses were done with help of descriptive statistics and Chi-square $\left(\chi^{2}\right)$ or Fisher's Exact Probability Test. Data presented on categorical scale were compared between case and control group using Chi-square $\left(\chi^{2}\right)$ or Fisher's Exact Probability Test. Level of significance for all analyses was set at 0.05 and $p$-value $<0.05$ was considered significant.

\section{RESULTS}

Table I : Distribution of age between cases and controls.

$\begin{array}{lll}\text { Age(months) } & \begin{array}{l}\text { Group } \\ \text { Case }(\mathrm{n}=\mathbf{6 5})\end{array} & \text { Control }(\mathrm{n}=\mathbf{6 5}) \\ 6-12 & 27(41.5) & 34(52.3) \\ 13-18 & 13(20.0) & 11(16.9) \\ 19-24 & 5(7.7) & 6(9.2) \\ >24 & 20(30.8) & 14(21.6)\end{array}$

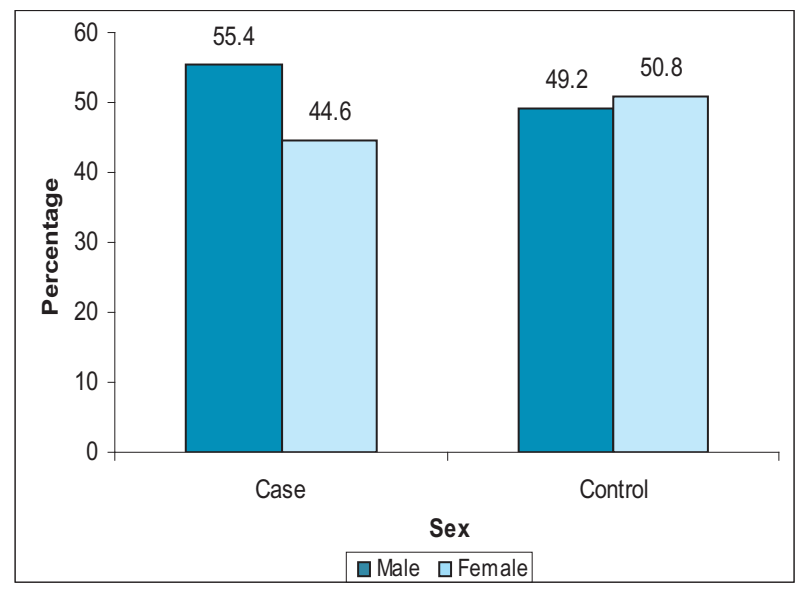

Figure 1 : Distribution of cases and controls by sex.

Table 2 : Comparison of prelacteal meal between cases and controls.

\begin{tabular}{lllll}
$\begin{array}{l}\text { Prelacteal } \\
\text { meal }\end{array}$ & Case $(\mathrm{n}=\mathbf{6 5})$ & $\begin{array}{l}\text { Group } \\
\text { Control }(\mathrm{n}=\mathbf{6 5})\end{array}$ & $\begin{array}{l}\text { Odds Ratio } \\
(\mathbf{9 5 \%} \text { CI of OR) }\end{array}$ & p-value \\
None & $21(32.3)$ & $38(58.5)$ & $2.92(1.60-5.51)$ & 0.008 \\
$\begin{array}{l}\text { Prelecteal } \\
\text { meal }\end{array}$ & $44(67.7)$ & $27(41.5)$ & & \\
\hline
\end{tabular}

Table 3 : Comparison of initiation of breast feeding between groups.

\begin{tabular}{lllll}
$\begin{array}{l}\text { Initiation of } \\
\text { breast feeding }\end{array}$ & \multicolumn{3}{c}{ Group } & p-value \\
& $\begin{array}{l}\text { Case } \\
(\mathbf{n}=\mathbf{6 5})\end{array}$ & $\begin{array}{l}\text { Control } \\
(\mathbf{n}=\mathbf{6 5})\end{array}$ & $\begin{array}{l}\text { Odds Ratio } \\
(\mathbf{9 5} \% \text { CI of OR })\end{array}$ & \\
$\begin{array}{l}\text { Ever breast } \\
\text { milk given }\end{array}$ & & & & \\
Yes & $61(93.8)$ & $65(100.0)$ & \\
No & $4(6.2)$ & 00 & & \\
$\begin{array}{l}\text { Initiation of } \\
\text { breast feeding }\end{array}$ & & & & \\
$\begin{array}{l}\text { Within 24 hour } \\
\text { of birth }\end{array}$ & $45(73.5)$ & $64(98.5)$ & & \\
$\begin{array}{l}\text { After 24 hours } \\
\text { of birth }\end{array}$ & $16(26.5)$ & $1(1.5)$ & $17.22(3.8-108.5)$ & $<0.001$ \\
\hline
\end{tabular}

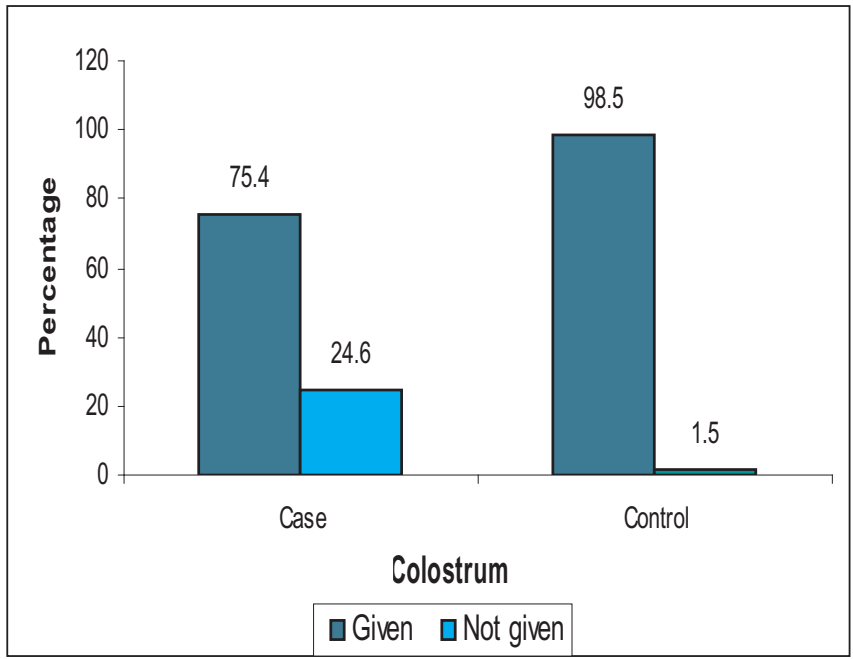

Figure 2 : Distribution of cases and controls by colostrum feeding.

Table 4 : Comparison of exclusive breast feeding between groups.

\begin{tabular}{|c|c|c|c|c|}
\hline \multirow[t]{2}{*}{ Breast feeding } & \multicolumn{4}{|c|}{ Group } \\
\hline & Case $(n=65)$ & Control $(n=65)$ & $\begin{array}{l}\text { Odds Ratio } \\
\text { (95\% CI of OR) }\end{array}$ & p-value \\
\hline \multicolumn{5}{|l|}{$\begin{array}{l}\text { Exclusive } \\
\text { breast feeding }\end{array}$} \\
\hline Yes & $20(31.3)$ & $38(58.5)$ & & 0.003 \\
\hline No & $45(68.7)$ & $27(41.5)$ & & \\
\hline \multicolumn{5}{|l|}{$\begin{array}{l}\text { Duration of } \\
\text { exclusive } \\
\text { breast feeding } \\
\text { (months) }\end{array}$} \\
\hline$<6$ & $11(55.0)$ & $7(18.4)$ & $5.57(2.79-11.20)$ & $<0.001$ \\
\hline$\geq 6$ & $9(45.0)$ & $38(81.6)$ & & \\
\hline
\end{tabular}


Table 5 : Comparison of predominant \& partial breast feeding between group.

\begin{tabular}{llll} 
Breast feeding & \multicolumn{2}{c}{ Group } & p-value \\
& Case $(\mathbf{n}=\mathbf{6 5})$ & Control $(\mathbf{n}=\mathbf{6 5})$ & \\
$\begin{array}{l}\text { Duration of } \\
\text { predominant } \\
\text { breast feeding }\end{array}$ & & \\
$<6$ months & $20(30.8)$ & $4(6.2)$ & \\
up to 6 months & $4(6.2)$ & $6(9.2)$ & 0.001 \\
$>6$ months & $12(18.5)$ & $12(18.5)$ & \\
$\begin{array}{l}\text { Partial breast } \\
\text { feeding\# }\end{array}$ & & \\
Yes & $21(34.4)$ & $9(13.8)$ & \\
No & $44(65.6)$ & $56(86.2)$ & \\
\hline
\end{tabular}

Table 6 : Comparison of breast milk substitute between groups.

\begin{tabular}{|c|c|c|c|}
\hline \multicolumn{4}{|c|}{$\begin{array}{l}\text { Breast milk supplements } \\
\text { within } 6 \text { month of age* } \quad \text { Group }\end{array}$} \\
\hline & Case $(n=25)$ & Control $(n=9)$ & p-value \\
\hline Formula milk & $19(76.0)$ & $9(100.0)$ & $<0.001$ \\
\hline Cow's milk & $6(24.0)$ & $0(0.0)$ & \\
\hline
\end{tabular}

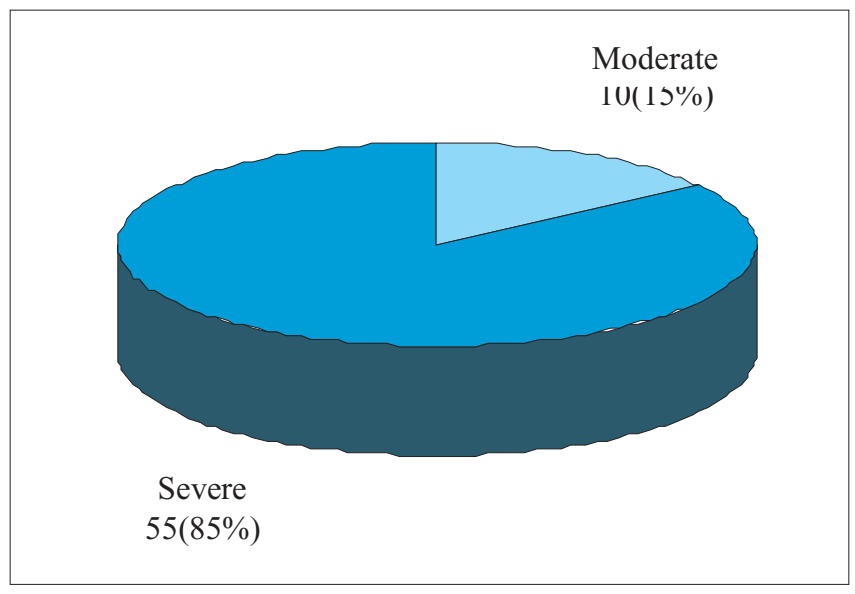

Figure 3 : WHO classification of malnutrition.

\section{DISCUSSION}

Protein energy malnutrition is still a major health problem in children of developing countries including Bangladesh. The findings of the present study aimed at identifying the risk factors for faulty breast feeding practice, therefore, need to be compared and contrasted with the studies conducted to the same end at home and abroad.
As demographic characteristics of the subjects are considered, the mean age of the cases $(19.7 \pm 13.0$ months $)$ was found to be significantly higher than that of controls (13.5 \pm 7.8 months) (p $<0.01$ ), although the sex distribution between groups was almost homogeneous. Amin et al. found majority $(88 \%)$ of the malnourished children below 3 years of age. However, $30 \%$ of the malnourished children in our study were above 2 years of age. Mollah et al. found the mean age 12.3 months $^{10,11}$.

A significantly higher frequency of cases $(67.7 \%)$ were given pre-lacteal feed predominantly honey and sugar water compared to control group $(41.5 \%)(\mathrm{p}=0.008)$. The rest $58.5 \%$ of the control group were not given any prelacteal feed. The widely practiced prelacteal feeding could be explained by the ritualistic feeding practices and lack of confidence of mothers about sufficiency of breast milk produced during early lactation $^{12}$.

However, no significant difference was observed between cases and control group with respect to breast milk ever given ( $\mathrm{p}=$ 0.119 ). But in terms of initiation of breast feeding $80 \%$ of the mothers of control group initiated it within half an hour of birth of their babies compared to $44.3 \%$ of mothers of the case group $(p<0.001)$. Early initiation of breast feeding preferably within half an hour of birth help to develop strong suckling reflex and successful lactation ${ }^{13}$.

Nearly $100 \%$ of controls were given colostrum compared to $75 \%$ of the cases. The difference between cases and controls was statistically significant $(\mathrm{p}<0.001)$. Faulty Breast feeding practice including rejection of colostrums is among the most important causes of malnutrition. Haque et al. showed that colostrums feeding was significantly low $(p<0.01)$ and prelacteal feeding was significantly high $(\mathrm{p}<0.01)$ among the cases in comparison to the controls ${ }^{14}$.

About one-third (31.3\%) of the cases was exclusively breastfed in comparison to $58.5 \%$ of the control group ( $\mathrm{p}=0.003)$. Over one-quarter $(27.7 \%)$ of the controls was breast fed up to 6 months of age, as opposed to only $1.5 \%$ cases $(p<0.001)$ which is consistent with the study of Mollah et al. Early cessation of Breast feeding is a major cause of severe proteinenergy malnutrition among the under two children. This was shown in a recent study in Tanzania ${ }^{11,15}$. Duration of predominant breast feeding for up to 6 months of age was also significantly higher in control group than that of case group ( $p$ $=0.001)$. Partial breast feeding demonstrates their significant presence in cases $(38.5 \%)$ than that in controls $(15.4 \%)$. Supplementation of breast milk with cow's milk and formula milk within 6 months of age was much higher in the case group than that in the control group $(\mathrm{p}<0.001)$.

WHO classification of malnutrition shows that majority $(85 \%)$ of the cases had severe malnutrition and rest $15 \%$ moderate malnutrition, while Welcome classification demonstrates that more than one-third (37\%) of the cases had marasmas, $18 \%$ had kwashiorkor and $45 \%$ had marasmic-kwashiorkor. In another study $50 \%$ of the malnourished children had marasmus, $16 \%$ had kwashiorkor and $34 \%$ marasmic kwashiorkor $^{16}$. 


\section{CONCLUSION}

The present study data suggest that current breast feeding practice do not conform to the recent recommendations, as rejection of colostrum, practice of prelateal feeding, delayed initiation of breast feeding, early cessation of exclusive breast feeding all were significantly high in the malnourished group of children than those in their normal counterpart. The faulty breast feeding practices such as rejection of colostrum, practice of prelacteal feeding, delayed initiation of breast feeding and early cessation of exclusive breast feeding are important risk factors for malnutrition.

\section{RECOMMENDATIONS}

In the light of findings of the study the following recommendations are put forward to improve the current breast feeding situation and to reduce the risk of malnutrition.

1. Colostrums rejection and giving prelacteal feed are still no less and the practice might be associated with superstitious beliefs, which need to be investigated further with the help of anthropological study.

2. Exclusive breast feeding should be continued up to 6 months and thereafter weaning should be started with adequate and appropriate food. However, breast feeding is to be continued up to 2 years.

\section{DISCLOSURE}

All the authors declared no competing interest.

\section{REFERENCES}

1. Waterlow JC. Protein-energy malnutrition. 1st ed. London: Edward Arnold. 1992; 1-2.

2. McLaren DS. A fresh look at protein calorie malnutrition. The Lancet. 1966; 2: 485-487.

3. Ghai OP, Gupta P, Paul VK. Nutrition and macronutrient disorders. In: Gupta P editor. Essential Paediatrics. New Delhi. 2005; (6) : 93-118

4. Anonymous. Malnutrition - the Global Picture. WHO, Geneva 2000.

5. Anonymous. The report of the world nutrition situation. United Nations Adminstrative Committee on coordination, sub-committee on nutrition (ACC/SCN), ACC/SCN Secretariat, Geneva 2000.

6. Bangladesh Bureau of Statistics. Child Nutrition Survey of Bangladesh 2000, Dhaka. Bangladesh Bureau of Statistics 2002

7. Islam MA, Rahman MN, Mahalanabis D. Maternal and socioeconomic factors and the risk of severe malnutrition in a child: a case control study. Eur J Clin Nutr. 1994; 48: 416-424.

8. Sadeque AJM, Jalaluddin M, Chowdhury MA. Magnitude of Malfeeding Practice among under 2 Children. CM-O-S (Child) H J. 2002; 1: $25-26$.

9. Anonymous. Breastfeeding Management and Promotion in a Baby-friendly Hospital. WHO/UNICEF Manual 1993.

10. Mollah MAH, Nahar N, Ahmed MU, Saha NC, Dey DK. Pattern of breast feeding and weaning practices among malnourished and weel-nourished under 2 years children. Bang J child Health. 1999; 23: 12-16.

11. Hussain MZ, Rahman SA, Afrosa A, Begum A et al. Serum Zinc level in malnourished children. Bang J Child Health. 2003;27:85-89.

12. Carbonare SB, Silva ML, Trabulsi LR. Inhibition of Hep-2 cell invasion by enteroinvasive E. coli by human colostrum IgA. Int Arch Allergy Immunol. 1995;108:113-118.

13. Akhter N. Cultural barriers in the promotion of breast feeding. Breast Feeding Bulletin. 1997; 3: 5.

14. Haque MF, Rahman SMM, Khan MR. Rejection of colostrum and its association with Protein Energy Malnutrition (PEM). Bang J Child Health. 2001; 25: 53-56.

15. Serventi M, Lago AMD, Kimaro DN. Early cessation of breast feeding as a major cause of severe malnutrition in under twos: A hospital based study-Dodoma region, Tanzania. East Af Med J. 1995;72:132-134.

16. Anoop S, Saravanan B, Joseph A, Jacob KS. Maternal depression and low maternal intelligence as risk factors for malnutrition in children: a community based case-control study from South India. Arch Dis Child. 2004; 89: 325-329. 